\title{
Prevalence of antichlamydial antibody in London blood donors
}

\author{
S DAROUGAR,* T FORSEY,* D A BREWERTON, $†$ AND K Ll ROGERS \\ From the *Department of Clinical Ophthalmology, Institute of Ophthalmology; the + Department of \\ Rheumatology, Westminster Hospital; and the $¥$ South London Blood Transfusion Centre, London
}

SUMMARY The prevalence of type-specific antichlamydial antibody in a population of blood donors in London was studied using a microimmunofluorescence test. Twenty-six (17\%) of 150 women and $38(26 \%)$ of 150 men had antichlamydial antibody (IgG at $\geqslant 1 / 16$ or $\operatorname{IgM} \geqslant 1 / 8$ or both). Of these, five (3\%) women and one $(0.75 \%)$ man had this antibody directed against Chlamydia trachomatis serotypes D-K, responsible for genital infections, and one man had antibody to Chlamydia psittaci agents. The remaining 57 men and women had antibody against an atypical chlamydial isolate designated Chlamydia IOL-207, which is iodine-negative and serologically distinct from both $C$ trachomatis and $C$ psittaci. The nature and location of infection by this agent are obscure.

The results of this study suggest that the prevalence of sexually transmitted infection with $C$ trachomatis serotypes $\mathrm{D}-\mathrm{K}$ in a normal adult population in London is very low.

\section{Introduction}

Chlamydial genital infection is a common sexually transmitted disease. Chlamydia have been isolated from up to $68 \%$ of men with nongonococcal urethritis (NGU), ${ }^{1}$ from up to $62 \%$ of women with gonorrhoea, ${ }^{2}$ and from up to $31 \%$ of unselected women attending a sexually transmitted diseases clinic. ${ }^{2}$ Ocular chlamydial infection of sexually transmitted origin-namely, TRIC ophthalmia neonatorum, inclusion conjunctivitis, and TRIC punctate keratoconjunctivitis-is also common, ${ }^{3}$ and evidence is accumulating that Chlamydia trachomatis may cause pneumonitis, ${ }^{4}$ pelvic inflammatory disease, ${ }^{5}{ }^{6}$ perihepatitis, peritonitis, ${ }^{7}$ and endocarditis. ${ }^{8}$

The rate of exposure to chlamydial agents, particularly to Chlamydia trachomatis, in communities is not known. In San Francisco an isolation rate of $11 \%$ was reported in women attending a birth control clinic, and in Seattle ${ }^{10}$ the chlamydial isolation rate in pregnant women having routine examinations was as high as $\mathbf{1 2 \cdot 7 \%}$. In this report we present the results of a study on the presence and concentrations of type-specific anti-

Address for reprints: Dr S Darougar, Institute of Ophthalmology, Judd Street, London WC1H 9QS

Received for publication 23 April 1980 chlamydial antibodies in a group of adult men and women blood donors in South London.

\section{Subjects and methods}

One hundred and fifty male and 150 female blood donors were selected from a population of volunteers attending a South London transfusion centre with a catchment area including Kent, Sussex, Surrey, and London. Their mean ages were $38 \pm 14$ and $40 \pm 13$ years respectively. The volunteers were apparently free from any major chronic diseases, were not under treatment, were feeling healthy at the time of blood donation, and were not known to be in contact with any infectious disease. Volunteers with overt herpes simplex virus infection or with known chronic urogenital infections requiring treatment were excluded.

Blood was collected by venepuncture; the serum was separated and kept at $-20^{\circ} \mathrm{C}$ for $2-4$ months until tested.

MICRO-IF TEST

The modified microimmunofluorescence (micro-IF) test of Treharne et $a l^{11}$ was used to detect antichlamydial antibodies in serum samples. These samples were screened for antichlamydial IgG and IgM at dilutions starting at $1 / 16$ and $1 / 8$ respectively. Goat anti-human IgG and IgM fluorescein-labelled conjugates (Hyland Division, Travenol Laboratories) 
TABLE I Type-specific antichlamydial antibody in sera from 150 female and 150 male blood donors

\begin{tabular}{lllll}
\hline & \multicolumn{3}{l}{ No of sera giving positive results } \\
\cline { 2 - 3 } & \multicolumn{2}{l}{ Women } & & Men \\
\cline { 2 - 5 } Chlamydial species & No & $\%$ & No & $\%$ \\
\hline C trachomatis & & & & \\
$\quad$ Serotypes A-C & 0 & 3 & 0 & \\
$\quad$ Serotypes D-K & 5 & & 1 & $0 \cdot 75$ \\
$\quad$ LGV serotypes 1-3 & 0 & & 0 & \\
$C$ psittaci & 0 & & 1 & $0 \cdot 75$ \\
Representatives ${ }^{11}$ & 0 & 14 & 36 & 24 \\
IOL-207 (atypical) & 21 & 17 & 38 & 26 \\
\hline All species & 26 & & & \\
\hline
\end{tabular}

were used at a dilution of $1 / 20$ for $\operatorname{IgG}$ and $1 / 10$ for IgM. Rhodamine conjugated bovine serum albumin (Difco Laboratories) at a dilution of $1 / 40$ was used as a counterstain. Sera were considered type-specific when the titre of antibody against a single antigen pool was at least twofold higher than against any other cross-reacting antigen. ${ }^{11}$ Other technical details of the micro-IF test have been described elsewhere. ${ }^{11} 12$

\section{Results}

Antichlamydial antibody at any concentration was detected in $17 \%$ of women and $26 \%$ of men (table I and figure). Antichlamydial IgG (at titres $\geqslant 1 / 16$ ) against $C$ trachomatis serotypes D-K (responsible for genital and ocular infection) was detected in five $(3 \%)$ women and one $(0 \cdot 75 \%)$ man. Antichlamydial IgM was detected in only one woman, and this was also directed against $C$ trachomatis D-K. This patient also had IgG at a titre of 1/64 against serotypes D-K.

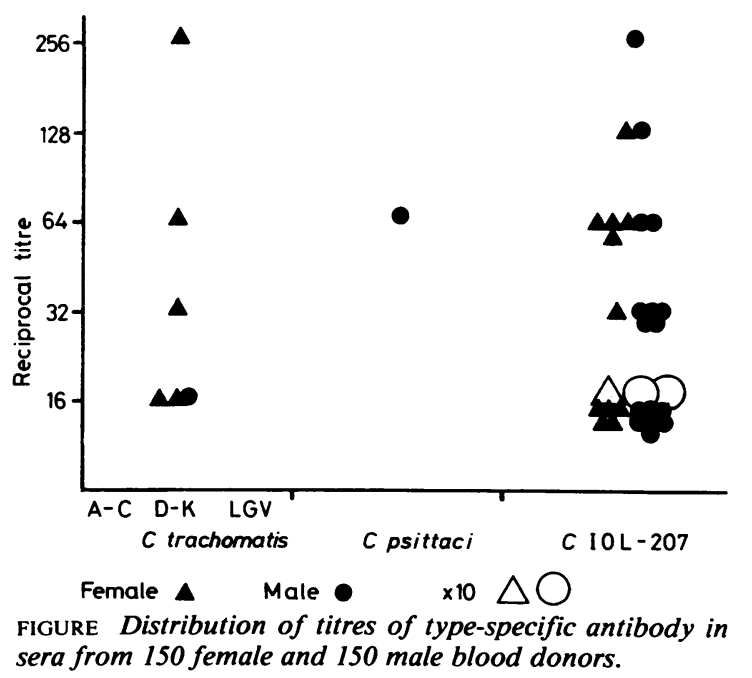

If IgG at a titre $\geqslant 1 / 64$ and IgM at a titre $\geqslant 1 / 8$ is taken as indicative of a current chlamydial infection, ${ }^{13}$ two women showed these significant micro-IF results against serotypes D-K.

Antichlamydial IgG at a titre of $1 / 64$ against representatives of Chlamydia psittaci was detected in the serum of one man. No antibody was detected against $C$ trachomatis serotypes A-C (responsible for hyperendemic trachoma) or the LGV serotypes.

Antichlamydial IgG (at a titre $\geqslant 1 / 16$ ) against TRIC/IR/IOL-207/OT (IOL-207), an atypical chlamydial isolate, ${ }^{12}{ }^{14}$ was detected in $21(14 \%)$ women and $36(24 \%)$ men. In nine of them IgG was detected at a titre $\geqslant 1 / 64$ (figure). No IgM antibody was detected against $C$ IOL-207. The cross-reactivity of sera showing antibodies against $C$ IOL-207 and $C$ trachomatis serotypes are shown in table II.

\section{Discussion}

Cell culture systems for isolation of chlamydia ${ }^{15-18}$ are sensitive for the diagnosis of chlamydial infections. Because of their technical complexities, however, and the particular requirements for collection and transport of specimens, ${ }^{19}$ these tests are not considered to be practicable for use in small diagnostic laboratories or in epidemiological surveys of chlamydial infections.

The modified micro-IF test used in the present study is a sensitive, simple, and rapid serological test for the detection of type-specific antichlamydial IgG, IgM, or IgA in whole blood, sera, or local discharges. Detection of type-specific antibody after screening of blood against four antigen pools which correspond with each of the four main clinical and epidemiological types of chlamydial infections--that is, hyperendemic trachoma (C trachomatis serotypes A-C), ocular and genital infections of sexually transmitted origin (C trachomatis serotypes D-K), lymphogranuloma venereum ( $C$ trachomatis LGV agents 1-3), and $C$ psittaci infections (representative isolates of $C$ psittaci) - may indicate which clinical and epidemiological type of infection is implicated.

In the present study, antibody against $C$ trachomatis serotypes D-K was detected in five (3\%) of 150 of the women and in one $(0.75 \%)$ of 150 of

TABLE II Cross-reactivity of 57 sera showing IgG antibody against Chlamydia IOL-207

\begin{tabular}{lrrrrr}
\hline & \multicolumn{6}{l}{ IgG titre against $C$} & IOL-207 \\
\cline { 2 - 6 } IgG titre against & 16 & 32 & 64 & 128 & 256 \\
\hline trachomatis serotypes & 16 & 5 & 5 & & \\
\hline 0 & 43 & 5 & 1 & 1 & \\
16 & & & & 1 & 1 \\
32 & & & & & 1 \\
64 & & & &
\end{tabular}


the men tested. Studies by Treharne $e t$ al ${ }^{11}$ showed that in women with non-specific cervicitis the percentage of chlamydial isolation-positive patients with antibody titres $\geqslant 1 / 8$ was $77 \%$ whereas only $14 \%$ of isolation-negative patients showed antibody at this titre or higher. In men with non-specific urethritis, the percentage of chlamydial isolation-positive patients with antibody at this titre was $51 \%$ whereas in isolation-negative patients antibody was detected in only $10 \%$. These findings may suggest that the micro-IF positivity rate in women corresponds with the results of cell culture for defining chlamydial infection, whereas the micro-IF positivity rate in men may underestimate the frequency of the infection by approximately $50 \%$ in comparison with the cell culture system.

The prevalence of infection with $C$ trachomatis D-K serotypes obtained in our group of healthy adults from South London is markedly lower than that obtained in Seattle, USA, where antibody against $\boldsymbol{C}$ trachomatis $\mathrm{D}-\mathrm{K}$ was detected by a microIF test in $26 \%$ of the normal adult population. ${ }^{20}$ This marked difference in prevalence, however, may partly reflect different patterns of sexual activity and the socioeconomic status of the people included in the two investigations and may be partly due to the testing of sera at the lower dilution of $1 / 8$ by the workers in Seattle.

In the present study antibody against the chlamydial agent IOL-207 was detected in the blood of $14 \%$ of female and of $24 \%$ of male blood donors. $C$ IOL-207 is an atypical iodine-negative chlamydial isolate obtained from the eye of an Iranian child with trachoma using an egg-culture system. We found that this agent has certain properties in common with $C$ trachomatis and $C$ psittaci but is serologically distinct from both of these chlamydial species (unpublished data). Experimental inoculation of a baboon ${ }^{14}$ demonstrated the pathogenicity of this organism for the conjunctiva and urethra. During this experimental work we found that cell culture is not sensitive for reisolation of $C$ IOL-207 but that the organism can be reisolated in egg culture if several passages were attempted (unpublished data). The high frequency of antibody against C IOL-207 detected in our group of blood donors and in the blood of patients reported by Dwyer et al ${ }^{12}$ may suggest that infection by $C$ IOL-207 is rather common in certain communities. Because of the apparent insensitivity of the cell culture systems commonly in use for isolating chlamydia, however, the nature and location of infection caused by this agent is still obscure.

The pattern of cross-reactions obtained by the micro-IF test when sera positive (at a titre $\geqslant 1 / 16$ ) for $C$ IOL-207 are reacted against $C$ trachomatis antigens is shown in table II. As may be observed, if the $C$ IOL-207 antigen was excluded from this test four out of 57 sera would have been falsely recorded as having antibody titres $\geqslant 1 / 16$ to $C$ trachomatis alone. We have also found that more cross-reactions occur between all chlamydial antigens when lower dilutions of sera are tested (unpublished data).

$C$ psittaci agents are commonly pathogenic for mammals and birds and occasionally may infect man. The presence of antibody against $C$ psittaci antigens in one male blood donor may suggest an infection with one of the various $C$ psittaci agents, including psittacosis infection.

This study was supported by grants from the Department of Health and Social Security and an anonymous donor.

\section{References}

1. Alani MD, Darougar S, Burns DC, Thin RN, Dunn $\mathbf{H}$. Isolation of Chlamydia trachomatis from male urethra. $\mathrm{Br} J$ Vener Dis 1977;53:88-92.

2. Hilton AL, Richmond SJ, Milne JD, Hindley F, Clarke SKR. Chlamydia $\mathrm{A}$ in the female genital tract. $\mathrm{Br} J$ Vener Dis 1974;50:1-10.

3. Anonymous. Chlamydial infections of the eye. Lancet 1977; ii: 857-8.

4. Beem MO, Saxon EM. Respiratory tract colonization and a distinctive pneumonia syndrome in infants infected with Chlamydia trachomatis. N Engl J Med 1977;296:306-10

5. Mårdh P-A, Svensson L, Weström L. Chlamydia trachomatis infection in patients with acute salpingitis. $N$ Engl $J$ Med 1977; 296: 1377-9.

6. Treharne JD, Ripa KT, Mårdh P-A, Svensson L, Weström L, Darougar S. Antibodies to Chlamydia trachomatis in acute salpingitis. Br J Vener Dis 1979; 55:26-9.

7. Müller-Schoop JW, Wang S-P, Munzinger J, Schlapfer HU, Knoblauch M, Ammann RW. Chlamydia trachomatis as a possible cause of peritonitis and perihepatitis in young women. Br Med J 1978; i: 1022-4.

8. Van der Bel-Kahn JM, Watanakunokorn C, Menefee MG, Long HD, Dicter R. Chlamydia trachomatis endocarditis. Am Heart J 1978;95:627.

9. Schacter J. Chlamydial infections. $N$ Engl $J$ Med 1978; 298:490-5.

10. Alexander ER, Chandler J, Pheifer TA, Wang S-P, English M, Holmes KK. Prospective study of perinatal Chlamydia trachomatis infection. In: Hobson D, Holmes KK, eds. Nongonococcal Urethritis and Related Infections. Washington DC: American Society for Microbiology, 1977:148-52.

11. Treharne JD, Darougar S, Jones BR. Modification of the micro-immunofluorescence test to provide a routine serodiagnostic test for chlamydial infection. J Clin Pathol 1977; 30:510-7.

12. Dwyer RStC, Treharne JD, Jones BR, Herring J. Chlamydial infection. Results of micro-immunofluorescence test for the detection of type-specific antibody in certain chlamydial infections. Br $J$ Vener Dis 1972; 48:452-9.

13. Treharne JD, Darougar S, Simmens PD, Thin RN. Rapid diagnosis of chlamydial infections of the cervix. Br J Vener Dis 1978; 54:404-8.

14. Darougar S, Monnickendam MA, El-Sheikh H, Treharne JD, Woodland RM, Jones BR. Animal models for the study of chlamydial infections of the eye and genital tract. In: Hobson D, Holmes KK, eds. Nongonococcal Urethritis and Related Infections. Washington DC: American Society for Microbiology, 1977: 148-52. 
15. Darougar S, Kinnison JR, Jones BR. Simplified irradiated McCoy cell culture for isolation of chlamydiae. In: Nichols RL, ed. Trachoma and Related Disorders. Amsterdam: Excerpta Medica, 1971:63-70.

16. Kuo C-L, Wang S-P, Wentworth BB, Grayston JT. Primary isolation of TRIC organisms in HeLa cells treated with DEAEDextran. J Infect Dis 1972; 125:665-8.

17. Wentworth BB, Alexander ER. Isolation of Chlamydia trachomatis by use of 5-iodo-2-deoxyuridine treated cells. Appl Microbiol 1974; 27:912-6.

18. Ripa KT, Mardh P-A. New simplified culture technique for Chlamydia trachomatis. In: Hobson D, Holmes KK, eds. Nongonococcal Urethritis and Related Infections. Washington DC: American Society for Microbiology, 1977:323-7.
19. Darougar S, Jones BR, Kinnison JR, Vaughan-Jackson JD, Dunlop EMC. Chlamydial infection. Advances in the diagnostic isolation of chlamydia, including TRIC agents, from the eye, genital tract and rectum. Br $J$ Vener Dis $1972 ; 48: 416-20$.

20. Wang S-P, Grayston JT, Kuo C-C, Alexander ER, Holmes KK. Serodiagnosis of Chlamydia trachomatis infection with the micro-immunofluorescence test. In: Hobson D, Holmes KK, eds. Nongonococcal Urethritis and Related Infections. Washington DC: American Society for Microbiology, 1977:237-48. 